\title{
RUSKA MILOŚĆ W CZASACH AUTONOMII GALICYJSKIEJ, CZYLI O ROMANSACH W BIBLIOTEKACH GRECKOKATOLICKIEGO DUCHOWIEŃSTWA ${ }^{1}$
}

Słowa kluczowe: Galicja, Starorusini, rusofile, romans, architektura wyboru

Keywords: Galicia, Old Ruthenians, russophiles, romance novel, architecture of choice

\author{
RUTHENIAN LOVE IN THE TIME OF GALICIAN AUTONOMY: \\ ROMANCES IN THE LIBRARIES OF THE GREEK CATHOLIC CLERGY
}

$$
\text { S u m m a ry }
$$

The article presents how the libraries of Greek Catholic priests in the Galician clergy houses of the second half of the $19^{\text {th }}$ century shaped and managed the horizon of the matrimonial expectations of Ruthenian readers i.e. daughters of the priests. I interpret romance novels by Ivan Havryshkovych (1827-1907) and Fylymon Kalytovsky (1841-1912) which were addressed to them and printed in a literary supplement to the conservative Ruthenian magazine "Slovo". The issue under consideration has not been the subject of literary studies so far.

I treat these literary texts as an artistic representation of the Galician social structure. The overarching aim of the research is to interpret, using the sociological theory of Eva Illouz, the ecology and architecture of romantic choices of the Ruthenian elite. More specifically, I look at the socially shaped matrimonial conditions reflected in the romances and conventions that accompany them, as well as at the relationship of romantic choices with social transgression of the protagonists.

Moreover, I attempt to show what political factors formed and disciplined the literary representations of erotic love and what these representations can tell us about the socio-national order in Galicia designed by conservative Ruthenian writers.

\section{Biblioteczka popadianki albo galicyjskie marginalia}

Plebanie greckokatolickie w Galicji drugiej połowy XIX wieku, wyposażone przez księży w księgozbiory wzorowane - tylko formalnie - na tych z dworów szlacheckich, pełniły rolę lokalnych centrów ruskiej kultury duchownej i świeckiej.

${ }^{1}$ Artykuł powstał w wyniku realizacji projektu badawczego o $\mathrm{nr}$ 2016/20/S/HS2/00584 finansowanego ze środków Narodowego Centrum Nauki. 
„Atenami Ruskimi” nazywano plebanię księdza Iwana Ozarkiewicza (1826-1903) z Bolechowa. Biblioteka duchownego ukształtowała nowoczesny światopogląd jego córki - Natalii Kobryńskiej (1855-1920). Lektury przyszłej emancypantki, pisarki i społeczniczki mogły jednak stanowić wyjątek od reguły, bowiem księża i ich rodziny reprezentowali w większości poglądy zachowawcze. Odzwierciedlało to charakter galicyjskiego ruchu ruskiego w latach 60.-80. XIX wieku, zdominowanego przez Rusinów-konserwatystów (głównie elitę duchowną). Stąd córki księżowskie, popadianki, zadowalały swe gusta czytelnicze przeważnie literaturą religijną lub beletrystyką romansową.

Tę ostatnią uważam za obiecujący materiał badawczy. Nieobecne we współczesnej historii literatury ukraińskiej romanse konserwatystów traktuję bowiem jako reprezentację normatywnych w latach $60 .-80$. dyskursów na temat relacji społecznych, które kształtowały i zarządzały horyzontem oczekiwań matrymonialnych czytelniczek. Lokalizacja tej twórczości poza sferą zainteresowań literaturoznawców wynika z marginalnej pozycji gatunków romansowych w dziejach piśmiennictwa oraz wyłączenia spuścizny prozaików związanych z ówczesnymi konserwatystami ruskimi z historii literatury ukraińskiej do dziś przedstawiającej jedynie narracje narodowców-ukrainofilów. Rekonstrukcja biblioteczek popadianek, córek ruskich tradycjonalistów, może zatem przybrać formę - parafrazując bell hooks - „miejsca radykalnego otwarcia”, czyli zainicjować taki proces interpretacyjny, który stworzy alternatywny punkt widzenia na literaturę, obyczajowość i społeczeństwo galicyjskie.

Przyczynkiem do powyższego będzie interpretacja wybranych powieści publikowanych w 1867 roku na łamach dodatku beletrystycznego do lwowskiego czasopisma „Słowo” („Слово”) 2 . Skoncentruję się na podstawowych komponentach wątków fabularnych prozy romansowej: miłości, erotyce i wyborach matrymonialnych ${ }^{3}$ oraz ich uwikłaniu w postulowany przez autorów ład kulturowy. Ograniczenie czasowe wynika nie tylko z faktu, że właśnie w 1867 roku ujrzał światło dzienne pierwszy numer „Galicjanina. Dodatku naukowo-beletrystycznego do «Słowa»” („Галичанинъ. Науково-белетристичная прилога до «Слова»", 1867-1870). Inicjatywy wydawnicze stanowily bowiem wynik fermentu wewnątrz nieukrainofilskiej elity ruskiej, na którą składały się dwie zachowawcze pod względem społecznym, kulturowym i obyczajowym frakcje: staroruska

${ }^{1}$ Vide bell hooks, „Margines jako miejsce radykalnego otwarcia”, trans. Ewa Domańska, Literatura na Świecie, no. 1-2 (2008): 108-117.

${ }^{2}$ Jedno z najważniejszych i opiniotwórczych czasopism ruskich o charakterze społeczno-polityczno-literackim, wychodziło w latach 1861-1872 we Lwowie, od 1866 r. uznawane za główny organ prasowy rusofilów galicyjskich. Vide Мирослав Романюк, Марія Галушко, Украӥнські часописи Львова 1848-1939, vol. 1 1848-1900 (Львів: Світ, 2001), 183-196.

${ }^{3}$ Vide Anna Martuszewska, Architektonika literackiego romansu (Gdańsk: słowo/obraz terytoria, 2014), passim. 
i rusofilska ${ }^{4}$. Przyczyny fermentu leżały w zagrożeniu spowodowanym ówczesną ugodą między Wiedniem a szlachtą polską oraz powstaniem autonomii polskiej w Galicji. Z tego powodu w polemikach prasowych pojawily się argumenty rusofilskie ${ }^{5}$. Elita rusofilska, wychodząc z założenia, że istnieje wspólna dla Słowian wschodnich panruska przestrzeń kulturowa, postulowała uznanie przynależności do niej Rusinów galicyjskich. Deklaracja ta oznaczała odejście od dominującego wśród Starorusinów konceptu rozwoju narodu ruskiego ograniczonego do Galicji. Otwierała bowiem możliwość utożsamienia się z wysoką kulturą rosyjską - rozumianą jako wspólna i reprezentatywna dla całego świata wschodniosłowiańskiego. Identyfikacja ta miała bronić Rusinów przed polonizacją i latynizacją, czego - zdaniem rusofilów - nie była w stanie zagwarantować kultura ruska w samej monarchii habsburskiej ${ }^{6}$. Ponadto część Rusinów, wyobrażając sobie swój udział w wysokiej kulturze rosyjskiej/panruskiej, utwierdzała tym samym dystynkcje wewnątrz własnej społeczności galicyjskiej, polegające na wyakcentowaniu różnic między elitą a chłopstwem.

W sferze literatury poglądy konserwatywne autorów polegały między innymi na wierności zasadzie decorum - używaniu ruskiego języka książkowego w tekstach skierowanych do wyższych warstw Rusinów galicyjskich. Opierał się on na etymologiczno-historycznych regułach pisowni oraz w dużej mierze na języku cerkiewnosłowiańskim, a nie na dialektach ruskich (to w swym demokratycznym projekcie narodowym postulowali już wtedy ukrainofile) $)^{7}$. Analogiczną

${ }^{4}$ Starorusini byli lokalnymi patriotami ruskimi, lojalnymi wobec Wiednia, traktującymi szlachtę polską jako największe zagrożenie (od 1848 r. konsekwentnie domagali się podziału Galicji na część ruską i polską), a Cerkiew greckokatolicką jako fundament swej tożsamości. Rusofilów różnił od Starorusinów postulat jedności Rusinów habsburskich z istniejącą według nich ogólnoruską wspólnotą kulturową. Vide Paul Robert Magocsi, „Old Rythenianism and Russophilism: A New Conceptual Framework for Analyzing National Ideologies in Late 19th Century Eastern Galicia”, in American Contributions to the Ninth International Congress of Slavists, ed. Paul Debreczny, vol. 2 Literature, Poetics, History (Kiev: Slavica, 1983), 305-324; Filip Świstun, „Spory austryackich Rusinów o kwestyę narodowości”, Świat Słowiański, no. 71 (1910): 250-276; Олена Аркуша, Мар’ян Мудрий, „Русофільство в Галичині в середині XIX - на початку XX ст. Генеза, етапи розвитку, світогляд”, Вісник Львівського університету. Серія історична, nо. 34 (1999): 231-268; Анна Вероніка Вендланд, Русофіли Галичини. Украйнські консерватори між Австрією та Росією, 1848-1915, trans. Христина Назаркевич (Львів: Літопис, 2015); Остап Середа, „Між українофільством і панславізмом: До історії змін національної ідентичности галицько-руських діячів у 60-х роках XIX ст. (Спроба полібіографічного дослідження)", Journal of Ukrainian Studies, no. 35-36 (2011-2010): 103-119.

${ }^{5}$ Jako jeden z pierwszych dobitnie przedstawił je duchowny greckokatolicki Iwan Naumowicz (1826-1891) w artykule Pogląd na przyszłość. Vide Одинъ именемъ многихъ [Iwan Naumowicz], „Поглядъ въ будучность”, Слово, по. 59 (27.07.1866): 1-2.

${ }^{6}$ Vide Олена Аркуша, Мар'ян Мудрий, ор. cit., 258-259.

${ }^{7}$ Vide Міхаель Мозер, „«Язичіє» - псевдотермін в українському мовознавстві”, trans. Сергій Вакуленко, in idem, Причинки до історї̈ украӥнської мови, ed. Сергій Вакуленко (Харків: Прапор, 2009), 641-666. 
jednorodność stylistyczną zachowywali publikujący na łamach „Galicjanina” zupełnie dziś zapomniani prozaicy: Iwan Hawryszkowicz (1827-1907) i Fyłymon Kałytowski (1841-1912). Obecna w ich romansach zasada odpowiedniości nie dotyczyła jedynie warstwy językowej, bowiem kreowany przez autorów romansowy świat przedstawiony urządzony został zgodnie z decorum matrymonialnym, pod którym rozumiem zgodność lokowania uczuć przez protagonistów z ich pozycją społeczną, kulturową i narodową oraz przystawalność podejmowanych działań do ich intencji i panujących konwenansów.

Swoistość owego decorum romansu ruskiego można ukazać pełniej, jeśli wziąć pod uwagę siły instytucjonalne mające wpływ na jego formowanie - Cerkiew i kler greckokatolicki, który stanowił większość wśród ówczesnej konserwatywnej elity ruskiej (na przykład wspomniany prozaik Hawryszkowicz był proboszczem, a sędzia i pisarz Kałytowski pochodził z rodziny księżowskiej). To zasady moralne i obyczajowość greckokatolicka, w tym brak celibatu, wywierały wpływ na wyobrażenia elit ruskich o miłości, erotyce, zalotach, ślubie, małżeństwie i rodzinie. Dominacja rodzin duchownych w społeczności ruskiej przyczyniła się do szczególnej pozycji samej instytucji rodzinnej, którą traktowano jako swego rodzaju axis mundi - sakralny punkt odniesienia dla tożsamości i fundament ładu moralnego. Ożenek księdza stał się synekdochą odrębności kultury ruskiej od polskiej, a szerzej: kultury wschodniej od kultury łacińskiej. Trwanie przy nim było argumentem na korzyść wyższości własnych tradycyjnych wartości, takich jak: rodzina, moralność publiczna i osobista, życie dla wspólnoty, przeciwstawianych cechom uznawanym jako właściwe dla polskiej kultury rzymskokatolickiej, czyli: celibatowi, amoralności, karierowiczostwu i egocentryzmowi ${ }^{8}$.

Powyższe komponenty konserwatyzmu ruskiego stanowią, jak powiedziałaby socjolożka Eva Illouz, ekologię i architekturę wyborów miłosnych XIX-wiecznej elity ruskiej w Galicji. Pod pojęciem ekologii badaczka rozumie warunki społeczne wpływające na wybór matrymonialny, natomiast architektury - usankcjonowane przez grupę społeczną praktyki towarzyszące dokonywaniu owych wyborów ${ }^{9}$. Kategorie te posłużą mi jako klucz interpretacyjny ruskiej ekologii i architektury wyboru miłosnego. Ponieważ kształtowały się one w etnicznie różnorodnej Galicji, w orbitę ich analizy wchodzi miłość oraz seksualność własna - parafialna i ruska, jak również inna - szlachecka i polska.

${ }^{8}$ Vide Андрій Заярнюк, „Соціальні аспекти статі в дискурсі греко-католицького духовенства Галичини другої половини XIX століття”, Україна Модерна, nо. 4-5 (2000): $50-80$.

${ }^{9}$ Eva Illouz, Dlaczego miłość rani. Studium socjologiczne, trans. Michał Filipczuk (Warszawa: Wydawnictwo Krytyki Politycznej, 2016), 46, passim. 


\section{Seksualność ujarzmiona}

W interesującym mnie czasie i przestrzeni kategorie narodowościowe i religijne zaczynały pełnić rolę odróżniania siebie od innych, choć nadal polaryzacje społeczne odgrywały istotną rolę w konstruowaniu tożsamości ${ }^{10}$. I to one stanowiły również rdzeń ekologii wyborów miłosnych bohaterów romansu łotrzykowskiego Iwana Hawryszkowicza Pan. Pusta opowieść z życia uczniowskiego (Панъ. Пустый розсказъ зъ школярского житья). Prozaik nakreślił na tle XIX-wiecznego Lwowa i jego przedmieść humorystyczny obraz społeczeństwa: od arystokracji, przez mieszczan i przedmieszczan. Z perspektywy dzisiejszego odbiorcy kontekst narodowy powieści nie jest określony explicite, ale dla znających ówczesne realia czytelniczek, kultura mieszczańska miała charakter głównie polski. Właśnie polską strukturę Lwowa autor Pana wykorzystał jako kostium literacki skrywający ruskie wzorce kulturowe oraz projekty społeczno-narodowe.

Konwencja romansu łotrzykowskiego nie służyła deprecjonowaniu przez prozaika hierarchii społecznej. Utwór nie jest bowiem groteskową rewolucją, która w ujęciu Bachtinowskim miałaby obrócić na nice pozornie wieczne struktury. Dlatego nawet tymczasowe zawieszenie praw i karnawalizacja rzeczywistości lwowskiej stwarza nastrój dziwności, ale i immanentnego niepokoju oraz oczekiwania, kiedy wszystko wróci na swe miejsce.

Hawryszkowicz eksperymenty z transgresjami społecznymi przeprowadza na głównym bohaterze powieści - Porfiriuszu de Chapturze Hołojuszce. Ten modelowy romansowy łotrzyk wciela się w rolę amanta, oczarowującego panny i wdowy, arystokratki i mieszczanki. Wedle gimnazjalnej braci Porfiriusz to lwowskie wcielenie Falstaffa, Don Kichota i Don Juana w jednym - szlachcic chodaczkowy, wieczny student bez grosza przy duszy, oszust-megaloman, który w intratnym małżeństwie widzi ratunek przed wierzycielami. Gimnazjaliści, nie kryjąc uśmiechu politowania, nazywali go panem, choć był jedynie „,...] ироніею, антиподомъ, пародіею пана, lacus a non lucendo [...]"11.

Hołojuszka - wbrew panującym konwenansom - ma zdolność ciągłej zmiany swego środowiska społecznego. Rozkochuje w sobie i kradnie pocałunki ubogiej Nastunci Sołowijskiej z lwowskiego przedmieścia oraz arystokratce Harminie Chmarołomskiej z centrum miasta. Nieokrzesany erotyzm protagonisty nie jest funkcją ciała bohatera - raczej uzewnętrznia jego niejednoznaczną pozycję

\footnotetext{
${ }^{10}$ Vide Bernadetta Wójtowicz-Huber, „Ojcowie narodu”. Duchowieństwo greckokatolickie w ruchu narodowym Rusinów galicyjskich (1867-1918) (Warszawa: Wydawnictwa Uniwersytetu Warszawskiego, 2008), 83.

${ }^{11}$ Иванъ Гавришковичъ, „Панъ. Пустый розсказъ зъ школярского житья”, Галичанинъ. Науково-белетристичная прилога до „Слова”, no. 20 (1867), 313: „[...] ironią, antypodą, parodią pana, lacus a non lucendo [...]”. Jeśli nie zaznaczam inaczej, tłumaczenia są mojego autorstwa - K.G.
} 
społeczno-ekonomiczną. Ten szlachcic z kiesą żebraka wyłamuje się zarówno z porządku ciała, jak i klasy. Nie wymyka się jednak dyskursywizacji, w ramach której Hawryszkowicz współtworzy dla czytelniczek ruskich „prawdę” o zachowaniach nienormatywnych, aby móc włączyć je (zachowania i czytelniczki) w sieć społecznej kontroli sprawowanej przez elitę greckokatolicką (m.in. przy pomocy „niewinnego" księgozbioru na plebanii).

Niekonwencjonalne zachowanie erotyczne oraz nierespektowanie swego miejsca w hierarchii społeczno-ekonomicznej budują komiczną postać Hołojuszki. Wśród czytelniczek ruskich miał on wzbudzać śmiech politowania, ale i śmiech obronny przed seksualnością szlacheckiego protagonisty. Ponadto miłosna niestabilność bohatera świadczy o jego braku charakteru w ówczesnym rozumieniu tego słowa. Jak dowodzi Illouz, lektura XIX-wiecznych powieści uzmysławia, że w czasach przednowoczesnych charakter nie był rozumiany jako zbiór cech oryginalnych jednostki, polegał bowiem na „harmonii pragnienia oraz celu moralnego. Charakter jest zatem pewnego rodzaju zobiektywizowaną i uzewnętrznioną wersją wartości wyznawanych przez daną grupę społeczną" ${ }^{12}$. Stąd nieposiadający zdolności internalizacji norm społecznych Porfiriusz wprowadza dysharmonię w ruską przestrzeń pragnień, rytuałów i ról społecznych.

Zgodnie ze schematem romansu protagonista niestosujący się do ówczesnej ekologii i architektury wyboru prędzej czy później doznaje upokorzeń, bowiem sukces matrymonialny osiągają tyko ci, którzy szanują konwenanse i swój stan ${ }^{13}$. Hołojuszka musi zatem skończyć z intrygami i dokonać upokarzającej ekspiacji w obecności swych niedoszłych narzeczonych. Wyznanie to jest równoznaczne $\mathrm{z}$ akceptacją przez wszystkie postaci obowiązujących norm moralnych, ujarzmieniem seksualności i powrotem ciała na swe miejsce w strukturze społecznej ${ }^{14}$. Akt ten pośrednio dotyczy również bohaterek - Nastunci i Harminy. Zachowanie głównych aktorek w sztuce miłosnej Porfiriusza zdradza bowiem niejednoznaczność ich pozycji pod względem moralnym i społecznym. Dotyczy ona zamiłowania obydwu panien do wcielania się w inne role, dzięki czemu przekraczają wyznaczone swej płci granice obyczajowe. Maskarada ta obdarza bohaterki siłą sprawczą - to one w pewnym momencie przejmują inicjatywę w grze miłosnej.

Zdaje się, że przyczyną tych relacji à rebours jest łączące te trzy postaci półlub pełne sieroctwo. Skoro w rodzinie odbywają się pierwsze procesy kontrolowania cielesności, to w powieści Hawryszkowicza bohaterowie nie do końca

${ }^{12}$ Eva Illouz, op. cit., 44.

${ }^{13}$ Ibidem, 57.

${ }^{14}$ Nawiązuję do opisywanej przez Foucaulta tradycji wyznawania w kulturze Zachodu własnej seksualności, które ma za zadanie rozszerzyć wiedzę i kontrolę nad cielesnością i działalnością jednostki, aby ta nie przekroczyła swej społecznej użyteczności. Vide Michel Foucault, Historia seksualności, trans. Bogdan Banasiak, Krzysztof Matuszewski, Tadeusz Komendant (Warszawa: Czytelnik, 1995), 71-117. 
zostali im poddani. Brak reprezentującego wzorce patriarchalne ojca i ucieleśniającej chrześcijańską moralność matki nie stworzyły ram zabezpieczających ich przed „groźną” seksualnością. Ponadto zaburzone relacje rodzinne spowodowały, że podmiotowość graczy miłosnych przestała podlegać „ochronie i kurateli osób trzecich [...], które pełniły rolę arbitrów wymuszających respektowanie norm moralnych i obyczajowych" ${ }^{15}$.

Według konwencji gatunkowej ktoś jednak musi przyjąć funkcję owego arbitra, aby romans mógł zakończyć się pogodzeniem bohaterów i przywróceniem ładu w ekologii i architekturze wyboru miłosnego. Zostaje nią panna Chmarołomska, która na mocy swej wysokiej pozycji społecznej urządza relacje między postaciami. Zatem Hołojuszka ma zostać domowym marszałkiem pana Fujarowskiego i wziąć za żonę pannę Sołowijską. Ponieważ w schemacie fabularnym romansu ceni się pochodzenie, „pan” Porfiriusz nie powinien trafić pod strzechę Nastunci. Może natomiast spełnić marzenie awansu społecznego dziewczyny, poślubiając ją już jako zabezpieczony finansowo pan marszałek. Harmina tymczasem przyjmuje oświadczyny wysoko urodzonego pana Fujarowskiego.

Ujarzmienie seksualności bohaterów wiąże się z odzyskaniem przez nich charakteru, czyli z uwewnętrznieniem tradycyjnych norm i wartości społecznych. Co istotne, odbywa się ono za pomocą ruskiego kodu językowego i kulturowego, który jest narzędziem porządkującym literackie relacje społeczno-erotyczne. Biorąc pod uwagę fakt, że ówczesne odbiorczynie romansów ruskich - popadianki - w plebanii wiejskiej były wychowywane zgodnie z normami panującymi wśród mieszczańskiej klasy średniej ${ }^{16}$, romans Hawryszkowicza mógł służyć jako opowieść dydaktyczna kontrolująca panny, które aspirują do miejskiego awansu. Jednocześnie męska narracja w Panu urządza seksualność lwowską tak, aby nie była ona zagrożeniem dla cnoty przyszłej mieszczanki ruskiej. Prozaik zatem poprzez językową rutenizację polskiej kultury miasta dokonuje jej symbolicznej kolonizacji i tworzy przestrzeń wyobrażoną dla powstającej właśnie ruskiej klasy mieszczańskiej.

\section{Miłość jako transgresja społeczna}

Powieść Fyłymona Kałytowskiego Zamiana (Замғьнъ) zbudowana jest na fabularnym schemacie romansowym urozmaiconym sensacyjno-melodramatycznym motywem związanym z tytułową zamianą tożsamości bohaterów oraz elementami analizy historycznej, społecznej i obyczajowej. Czasoprzestrzeń utworu tworzy galicyjska wieś Biłobrody, dwór szlachecki i plebania greckokatolicka

\footnotetext{
${ }^{15}$ Eva Illouz, op. cit., 49.

${ }^{16}$ Андрій Заярнюк, op. cit., 72-74.
} 
na przełomie lat 20. i 30. XIX wieku. Losy osobiste bohaterów zostały uwikłane w szerszy kontekst polityczny powstania listopadowego oraz poprzedzającej go agitacji wśród mieszkańców Galicji. Okres ten jest punktem odniesienia dla wyborów tożsamościowych postaci, bowiem decyzja przyłączenia się lub nie do powstańców wiąże się z określeniem swej przynależności do grona gente Rutheni, natione Poloni lub ruskiej wspólnoty narodowej.

Wybory te są podporządkowane głównemu wątkowi romansowemu: miłości panny Stefanii - córki nieżyjącego greckokatolickiego proboszcza Biłobrodów oraz Artura - syna właściciela wsi, polskiego barona Bonapartego. „Чувство бывае часто смертію для реального житья"17 - wyznaje Stefania z pełna świadomością, że uczucie, które połączyło ją i Artura nie ma racji bytu w obliczu dzielącej ich różnicy społecznej oraz kulturowej. Dlatego bohaterka, będąca ostoją cnotliwości, jest powściaggliwa w okazywaniu emocji. Właśnie wysoki status moralny Stefanii rekompensuje jej społeczno-ekonomiczne podporządkowanie $^{18}$.

Zamiana to nie tylko opowieść o dowartościowaniu kobiety w galicyjskim systemie patriarchalnym, ale również ukazanie wysokiej pozycji ruskich, greckokatolickich wartości, które uosabia Stefania. Bezinteresowna miłość szlachcica Artura do półsieroty bez posagu jest jego obietnicą podwyższenia statusu społecznego popadianki, ale także potwierdzeniem możliwości poprawy sytuacji ekonomicznej elity ruskiej w Galicji. Rzecz jasna, pociągnęłoby to za sobą następstwa polityczne w stosunku do dzierżącej władzę szlachty polskiej. Jednak zanim do tego dojdzie, Stefania musi pokonać drogę pełną cierpień, by wzmocnić i jeszcze bardziej uszlachetnić siebie oraz swoją miłość; musi również utracić cały swój skromny dobytek, by emocje związane z możliwym awansem były jeszcze bardziej intensywne ${ }^{19}$.

Przyczyną cierpień protagonistki, ale i wszelkiego zła, które spotyka innych bohaterów, jest szwarccharakter romansu - baron Bonaparte, który nie przebiera

${ }^{17}$ Ф.И. [Филимонъ] Калитовский, „Замънъ”, Галичанинъ. Науково-белетристичная прилога до „Слова”, nо. 10 (1867), 156: „Uczucie często bywa śmiertelne w obliczu realnego życia”.

${ }^{18}$ Notabene podobne miejsce kobiety w romansie tłumaczy popularność gatunku wśród XIX-wiecznych czytelniczek. Zdaniem Illouz ,[...] miłość była tak nieodparcie atrakcyjna, ponieważ zarówno przesłaniała, jak i rekompensowała głębokie nierówności kryjące się w samym sercu relacji genderowych” - Eva Illouz, op. cit. Cf. Agnieszka Setecka, „Romans - przejaw zwycięstwa czy klęski kobiet? O romansie dawniej i dziś”, in Krytyka feministyczna. Siostra teorii $i$ historii literatury, ed. Grażyna Borkowska, Liliana Sikorska (Warszawa: Instytut Badań Literackich PAN. Wydawnictwo, 2000), 187-192.

${ }^{19}$ Jak podkreśla Illouz, w XIX-wiecznych powieściach traktujących o miłości romantycznej interesowność nie była sprzeczna z miłością i planami matrymonialnymi, wręcz stawała się jej katalizatorem, małżeństwo miało bowiem zasadnicze znaczenie dla bytu ekonomicznego. Vide Eva Illouz, op. cit., 56. 
w środkach, aby przeszkodzić w mezaliansie syna. Ten właściciel Biłobrodów, przebiegły i bezlitosny, jest przykładem na to, że „[...] можна мати шляхоцтво на паперђ, но въ сердцю не бути шляхотнымъ ни на одробину" Dyskredytacja Bonapartego służy przede wszystkim uargumentowaniu poglądu, że on i jemu podobna szlachta nie posiada legitymacji moralnej do sprawowania władzy w Galicji. Dlatego zgodnie z zasadą sprawiedliwości literackiej dosięga go kara. Rolę powieściowej Nemezis odgrywa ruska chłopka Marta, w przeszłości ofiara gwałtu barona. W tym samym czasie, gdy żona Bonapartego powiła Artura, Marta urodziła Matwija - także syna barona. Wezwano ją wówczas do dworu jako mamkę. Powodowana pragnieniem polepszenia losu własnego dziecka, podmieniła chłopców i od tej pory syna szlacheckiego wychowała jak swego, natomiast dziecko jej i barona rosło we dworze jako Artur. Bohaterka pozbawiła Bonapartego możliwości przekazania majątku i władzy w ręce potomka z prawowitego łoża. Ponadto wychowany przez nią Matwij, nieświadom swej prawdziwej tożsamości, zabija barona, własnego ojca, pragnąc pomścić w ten sposób wyrządzone przez niego zło wśród biłobrodzkiej społeczności ruskiej.

Tu Kałytowski na krótko przenosi akcję do Królestwa Polskiego, gdzie Artur jako szlachcic polski przygotowuje powstanie przeciw Imperium Rosyjskiemu. Dzięki temu autor wprowadza narrację powieści w nurt galicyjskiego dyskursu rusofilskiego. Reprezentuje go napotkany przez Artura kapitan wojsk rosyjskich, z pochodzenia Małorusin, który zwraca się do gotowej do zrywu powstańczego szlachty polskiej słowami:

[...] не обвиняйте Россію, що она на васъ провинилась, що она оิтобрала вамъ житье политичне, - вы самы себе згубили!... Згадайте, якъ то предки ваши тратили маетки и кровавый трудъ народа на роскошное житье по заморскому обычаю або на роспусты за границею. Згадайте, що то прадъды ваши здълали съ нашою Мало-Русію! Згадайте притьсненія, гоненія, убійство цЊлого народа за тую одну вину, що оิнъ былъ въры православной! Знищили вы намъ нашу найкрасшу въ Славянщинъ землю - и васъ не минае за то кара Божа... ${ }^{21}$

${ }^{20}$ Ф.И. [Филимонъ] Калитовский, „Замђнъ”, Галичанинъ. Науково-белетристичная прилога до „Слова”, no. 11 (1867): 170: „,...] można mieć szlachectwo na papierze, ale w sercu nie być szlachetnym ni na krztynę".

${ }^{21}$ Ф.И. [Филимонъ] Калитовский, „Замђнъ”, Галичанинъ. Науково-белетристичная прилога до „Слова”, nо. 13 (1867): 204: „[...] nie obwiniajcie Rosji, że wobec was zawiniła, że odebrała wam życie polityczne - sami byliście dla siebie zgubą...! Przypomnijcie sobie, jak przodkowie wasi tracili majątki i krwawy trud ludu na rozkoszne życie wedle zamorskich zwyczajów albo na rozpustę za granicą. Przypomnijcie sobie, co pradziadowie wasi zrobili z naszą Małorusią! Przypomnijcie ucisk, prześladowania, zabójstwo całego narodu za tę jedną winę, że był wiary prawosławnej! Zniszczyliście nam naszą najpiękniejszą na Słowiańszczyźnie ziemię i nie omija was za to kara Boża...”. 
W warstwie ideologicznej utworu Rzeczpospolita zostaje przeciwstawiona sprawiedliwemu Imperium Rosyjskiemu, gdzie ruski lud prawosławny znalazł swe szczęście. Wartością naczelną porządku rosyjskiego był jakże atrakcyjny dla rusofilów konserwatyzm i taka pozycja duchowieństwa w Rosji, która gwarantowała mu pełne bezpieczeństwo. W obronie tego postulowanego także dla Galicji stanu na karatach Zamiany Rusini z Cesarstwa Austrii oraz Małorusini z Imperium Rosyjskiego jednoczą się i jako żołnierze rosyjscy biorą udział w thumieniu powstania listopadowego. Przyłącza się do tego dzieła również Matwij, który w ten sposób chce odpokutować grzech ojcobójstwa oraz pomścić krzywdy zadane ludowi przez szlachtę. Na tym dziejowym tle dochodzi do spotkania „janusowych” braci z Biłobrodów, którzy stanęli po przeciwnych stronach barykady. Spotkanie to dla powstańca Artura jest konfrontacją z jego ruską tożsamością, którą odnajduje w twarzy swego wychowanego przez Rusinkę polskiego brata. Po bitwie wraca do Galicji, ale już jako ruski panicz.

Artur z mlekiem swej mamki/matki wyssał pragnienie sprawiedliwości i nie chce przejmować majątku ojca, który „,czerwienieje od krwi ludu”. Jednak w konserwatywnej narracji romansowej pozytywnej postaci nie może spotkać degradacja społeczno-ekonomiczna. Na jakim kapitale mógłby zatem budować swą pozycję społeczną w Galicji bohater gente Rutheni? Odpowiedzi należy szukać ponownie poza granicami monarchii habsburskiej. Artur dziedziczy bowiem olbrzymi majątek po bezdzietnej ciotce Leokadii - mieszkającej w Warszawie wdowie po pułkowniku rosyjskim. Zatem to kapitał rosyjski, a nie polski daje bohaterowi niezależność finansową i matrymonialną. Dzięki temu władza i miłość trafia w ręce Rusinów: Artura i Stefanii. „[...] ты будешь добродњемъ для твоихъ поิдданыхъ, которы надъ собою мали лютого тирана!"22 - tymi słowami Marta, Rusinka i chłopka, ostatecznie wypełnia swój plan i symbolicznie mianuje syna na prawowitego ruskiego rządcę niezmiennie pańszczyźnianej wsi.

Konserwatyści ruscy ,[...] z upodobaniem wspominali czasy, kiedy to Ruś miała swoich bojarów, kniaziów, pod względem zaś politycznym skłonni byli do popierania wszelkiego absolutyzmu"23 - pisał na początku XX wieku historyk ruski Fyłyp Swystun (1844-1916). Przedstawiony przez Kałytowskiego literacki awans Stefanii i Artura w pańszczyźnianych ramach można uznać za fikcyjne spełnienie przywołanych przez Swystuna pragnień konserwatystów. „Janusowe” oblicze Artura/Matwija może posłużyć jako metafora tej wspólnoty pragnień polskich/ruskich konserwatystów. Różnica między nimi polegała natomiast na kapitale kulturowym i ekonomicznym, który w wyobrażonej przez rusofilów wspólnocie panruskiej miała zapewnić im jedyna niezależna państwowość słowiańska

${ }^{22}$ Ф.И. [Филимонъ] Калитовский, „Замђнъ”, Галичанинъ. Науково-белетристичная прилога до „Слова”, nо. 19 (1867): 299: ,[...] będziesz dobrodziejem dla swych poddanych, którzy nad sobą mieli okrutnego tyrana!".

${ }^{23}$ Filip Świstun, op. cit., 261. 
- Imperium Rosyjskie. Ponadto Kałytowski jako sędzia wywodzący się z rodziny księżowskiej odzwierciedlił w swej powieści tendencje wśród XIX-wiecznej inteligencji ruskiej polegające na budowaniu na gruncie duchowieństwa nowego pokolenia - elity świeckiej, która miała wchodzić jako niezależna siła do zmonopolizowanej dotąd przez Polaków przestrzeni władzy galicyjskiej.

\section{Księgi endogamii}

W XIX-wiecznych romansach Rusinów-konserwatystów wątek miłości wiązał się z motywem transgresji społecznej. Podstawowe pytania obecne w narracjach Iwana Hawryszkowicza i Fyłymona Kałytowskiego brzmiały: „w jakich okolicznościach (jeśli w ogóle) miłość zdolna jest pokonać bariery społeczne i na odwrót - czy przynależność do tej samej sfery socjoekonomicznej powinna stanowić konieczny warunek spełnienia miłości?"24.

W świecie przedstawionym interesujących mnie utworów miłość jest transgresyjna jedynie wtedy, gdy wiąże się z możliwością wkroczenia elity ruskiej w struktury władzy. Reprezentacje te dotyczą jej realnych dążeń pod koniec XIX wieku, gdy chcąc utrzymać swą pozycję, elita musiała wyjść poza sekularną kastowość i rozpocząć budowę własnej inteligencji świeckiej, konkurującej z dominującą w autonomii galicyjskiej szlachtą polską. Dlatego przynależność do sfery socjoekonomicznej nie stanowi warunku koniecznego w wyborze miłosnym protagonistów, oczywiście jeśli ten wybór jest na korzyść ruskich postaci. Stanowi go natomiast przynależność do wspólnoty narodowej (rusko-galicyjskiej lub ogólnoruskiej), co jest zrozumiałe w obliczu realnych zagrożeń polonizacji, których częstą przyczyną były małżeństwa mieszane. Romanse konserwatystów projektują zatem umacniającą kulturową i etniczną odrębność ruskiej elity endogamię, która pozwalała podjąć skuteczną rywalizację o sprawowanie władzy nie tylko duchowej, ale i świeckiej w Galicji wkraczającej w XX wiek wraz ze swoimi parafialnymi bibliotekami.

\section{Bibliografia}

Аркуша, Олена, Мар'ян Мудрий, „Русофільство в Галичині в середині XIX - на початку XX ст. Генеза, етапи розвитку, світогляд”, Вісник Львівського університету. Серія історична, по. 34 (1999): 231-268.

Вендланд, Анна Вероніка. Русофіли Галичини. Украӥнські консерватори між Австрією та Росією, 1848-1915, trans. Христина Назаркевич. Львів: Літопис, 2015.

Foucault, Michel. Historia seksualności, trans. Bogdan Banasiak, Krzysztof Matuszewski, Tadeusz Komendant. Warszawa: Czytelnik, 1995.

${ }^{24}$ Eva Illouz, op. cit., 19. 
Гавришковичъ, Иванъ. „Панъ. Пустый розсказъ зъ школярского житья”. Галичанинъ. Науково-белетристичная прилога до „Слова”, по. 20-27 (1867).

hooks, bell. „Margines jako miejsce radykalnego otwarcia”, trans. Ewa Domańska. Literatura na Świecie, no. 1-2 (2008): 108-117.

Illouz, Eva. Dlaczego miłość rani. Studium socjologiczne, trans. Michał Filipczuk. Warszawa: Wydawnictwo Krytyki Politycznej, 2016.

Калитовский, Ф.И. [Филимонъ]. „Замънъ”, Галичанинъ. Науково-белетристичная прилога до „Слова”, по. 9-19 (1867).

Magocsi, Paul Robert. „Old Rythenianism and Russophilism. A New Conceptual Framework for Analyzing National Ideologies in Late 19th Century Eastern Galicia”. In American Contributions to the Ninth International Congress of Slavists, ed. Paul Debreczny, Vol. 2 Literature, Poetics, History. Kiev: Slavica, 1983, 305-324.

Martuszewska, Anna. Architektonika literackiego romansu. Gdańsk: słowo/obraz terytoria, 2014.

Мозер, Міхаель. Причинки до істориї украӥнської мови, trans. Сергій Вакуленко et al., ed. Сергій Вакуленко. Харків: Прапор, 2009: 641-666.

Одинъ именемъ многихъ [Iwan Naumowicz]. „Поглядъ въ будучность”. Слово, nо. 59 (1866): 1-2.

Setecka, Agnieszka. „Romans - Przejaw zwycięstwa czy klęski kobiet? O romansie dawniej i dziś”. In Krytyka feministyczna. Siostra teorii $i$ historii literatury, ed. Grażyna Borkowska, Liliana Sikorska. Warszawa: Instytut Badań Literackich PAN. Wydawnictwo, 2000, 187-199.

Świstun, Filip. „Spory austryackich Rusinów o kwestyę narodowości”. Świat Stowiański, no. 71 (1910): 250-276.

Романюк, Мирослав, Марія Галушко. Українські часописи Львова 1848-1939, Львів: Світ, 2001.

Середа, Остап. „Між українофільством і панславізмом: До історії змін національної ідентичности галицько-руських діячів у 60-х роках XIX ст. (Спроба полібіографічного дослідження)", Journal of Ukrainian Studies, no. 35-36 (2010-2011): 103-119.

Wójtowicz-Huber, Bernadetta. „Ojcowie narodu”. Duchowieństwo greckokatolickie w ruchu narodowym Rusinów galicyjskich (1867-1918). Warszawa: Wydawnictwa Uniwersytetu Warszawskiego, 2008.

Заярнюк, Андрій. „Соціальні аспекти статі в дискурсі греко-католицького духовенства Галичини другої половини ХІХ століття”, Україна Модерна, no. 4-5 (2000): $50-80$. 